\title{
MINERALOGICAL, GEOCHEMICAL AND PALYNOLOGICAL STUDIES OF LATE HOLOCENE MANGROVE SEDIMENTS FROM NORTHEASTERN PARÁ STATE, BRAZIL
}

\author{
MARCONDES LIMA DA COSTA ${ }^{1}$, HERMANN BEHLING ${ }^{2}$, JOSÉ FRANCISCO BERRÊDO ${ }^{3}$, \\ MARCILÉIA SILVA DO CARMO ${ }^{1}$ \& NATALINO VALENTE MOREIRA DE SIQUEIRA ${ }^{1}$
}

\begin{abstract}
Mangroves constitute an expressive ecosystem in the northeastern Amazon region and one of the best examples of them is located in the marine coastal plain of Pará State close do Bragança City in northern Brazil. They were the subjects of our multidisciplinary researches carried out in past years. The gotten data included palynology, mineralogy, multi-element geochemistry and radiocarbon dating in order to get information about their formation conditions and transformation. This can help identify how this environment changed during the late Quaternary, mostly the paleoclimatic and continental-marine interaction in the region. The geological descriptions, the physicochemical data, the mineralogical and chemical composition and the multi-element geochemistry allow the identification of two zones in the 640-cm long drill core collected from the mangrove deposits. One acid, reduced and high salinity, rich in organic matter, clay minerals (smectite and kaolinite), halite, pyrite and feldspars from the surface up to $300 \mathrm{~cm}$; and the other from 300 to $640 \mathrm{~cm}$ in depth, alkaline, oxidizing, with low salinity, and rich in diatoms and quartz. The chemical composition displays a signature of terrigenous material like latosol derived from the Barreiras Formation, and of marine influence ( $\mathrm{Sr}, \mathrm{Ba}, \mathrm{Na}, \mathrm{K}$, $\mathrm{Mg}, \mathrm{Cl}$ and $\mathrm{F}$ ), as sources of material for the mangrove sediments. The pollen analyses and radiocarbon dates allow to identify three zones: the first two zones correspond to the near surface zone, deposited of low rates, in the last $1770 \mathrm{yr}$. The third zone can be correlated to alkaline and oxidizing zone. It was deposited from 2170 to $1770 \mathrm{yr}$. BP under high rates. The pollen diagram shows the domain of humid climate and the mineralogy and chemistry indicate a contribution of marine incursion and strong evaporation and oxidation close to the land surface.
\end{abstract}

Keywords: mangrove, mineralogy, geochemistry, palynology, radiocarbon, Pará State, Bragança, Amazon.

Resumo ESTUDOS MINERALÓGICOS, GEOQUÍMICOS E PALINOLÓGICOS DE SEDIMENTOS DE MANGUEZAIS DO NORDESTE DO ESTADO DO PARÁ Os manguezais constituem ecossistemas muito marcantes no nordeste da Amazônia e um dos melhores exemplos está localizado na planície costeira marinha do estado do Pará próximo à cidade de Bragança. Este foi objeto de pesquisas multidisciplinares (palinologia, mineralogia, geoquímica multi-elementar e datação por radiocarbono) no sentido de identificar as condições paleoambientais durante o Quaternário Recente, principalmente as paleoclimáticas e a interação entre as condições continentais e marinhas. Os dados geológicos, físico-químicos, a composição mineralógica e química, e a geoquímica multi-elementar permitiram identificar duas zonas distintas em um perfil do manguezal com $640 \mathrm{~cm}$ de profundidade: uma ácida, redutora, com alta salinidade, rica em matéria orgânica, argilominerais (esmectita e caulinita), halita, pirita e feldspatos, da superfície até $300 \mathrm{~cm}$; e outra alcalina, oxidante, com baixa salinidade, rica em diatomáceas e quartzo. A composição química apresenta assinatura de material terrígeno tipo latossolo derivado da Formação Barreiras além de influência marinha ( $\mathrm{Sr}, \mathrm{Ba}, \mathrm{Na}, \mathrm{K}, \mathrm{Mg}, \mathrm{Cl}$ e F) como fonte para os sedimentos dos manguezais. As análises de pólen e dados de radiocarbono permitem, por outro lado, identificar três zonas: as duas primeiras correspondem a parte do perfil próxima a superfície, depositada sob baixa taxa de sedimentação durante os últimos 1770 anos. A terceira zona é correlacionável com a alcalina oxidante, depositada de 2170 a 1770 anos AP sob altas taxas de sedimentação. O diagrama de pólen mostra o domínio de clima úmido e a composição mineralógica e química indicam ainda uma contribuição marinha e forte evaporação e oxidação próximo à superfície.

Palavras-chave: manguezais, mineralogia, geoquímica, palinologia, radiocarbono, Pará, Bragança, Amazônia.

INTRODUCTION Alluvial, estuarine and coastal plains with white sand beaches and mangrove vegetation characterize the northeastern coastal plain of Pará State in eastern Amazonia. The mangroves constitute a very sensitive ecosystem in this region. Mangroves occupy large areas and can be found up to $100 \mathrm{~km}$ from the coastline inland.

Mangrove have been studied in many regions of the world not alone because their importance as source of foods, but also for understanding this ecosystem. In Brazil studies are more recent and involve mainly their fauna and flora and the anthropogenic impacts. There are only a few geological studies, which are concentrated in a few Brazilian areas. The mangrove area of the Bragantina region in Pará is currently the subject of a multidisciplinary and inter-institutional study carried out by the Universidade Federal do Pará and the Center of Tropical Marine Ecology in Bremen, Germany, called Mangrove Dynamics and Management (MADAM). Several papers and theses have been published in the past five years, covering many aspects of the mangrove ecosystem (Behling et al. 2001, Reise \& Schories 2000, Rodrigues et al. 2000, Behling \& Costa 1997, Costa Neto et al.

\footnotetext{
I - Centro de Geociências, Universidade Federal do Pará, CEP 66075-110, Belém-PA, mlc@ufpa.br, marcileia@ufpa.br

2 - Center for Tropical Marine Ecology, Bremen Universitaet, 28359, Bremen Germany, hbehling@zmt.uni-bremen.de

3 - Coordenação de Ciências da Terra e Ecologia/Museu Goeldi Av.Perimetral, 1901, Terra Firme 66077-350 Belém-PA, berredo@museu-goeldi.br
} 
1996, Souza Filho \& El-Robrini 1996, Souza Filho 1995, Harbinson 1986, Harbinson 1984), but mineralogical and geochemical aspects of mangrove deposits have been poorly studied so far (Harbinson 1984, Harbinson 1986, Tanizaki-Fonseca 1994, Oliveira et al. 2002).

The present work aims to develop a mineralogical and geochemical study, supported by palynology, of mangrove deposits located at the Bragantina region (Fig. 1).

STUDY AREA The study was carried out in an extensive mangrove region near Bragança, North Brazil ( $0^{\circ} 52^{\prime} 427 \mathrm{~S}$ and 46 $36^{\circ} 012 \mathrm{~W}$ ). The Bragantina mangrove system has significantly changed within the last 20 years due to the construction of the road PA 458, linking the city of Bragança with the fisherman village Ajuruteua (Fig. 1). The study region has an average annual rainfall of $2500 \mathrm{~mm}$ with a distinguished wet season from January to June and a dry season from July to December. Average monthly air temperatures are between $25.2^{\circ} \mathrm{C}$ and $26.7^{\circ} \mathrm{C}$. Water salinity in the estuary varies from $38 \%$ at the end of the dry season to about $5 \%$ at the end of the rainy season (MADAM, unpublished data). The mean tidal range is about $3.5 \mathrm{~m}$, during spring tides exceed $5.0 \mathrm{~m}$ (Reise \& Schories 2000).

MATERIALAND METHODS Sampling The study site lies near the central part of Bragança peninsula in a mangrove forest, dominated by Avicennia trees. The sediment cores were collected in 50-cm long sections, using a Russian Sampler. The total core, called "Bosque de Avicennia", is $640 \mathrm{~cm}$ long. The drill cores were stored in the refrigerator. Seven sub-samples were taken from the core for the mineralogical and geochemical analysis. For pollen analysis, 0.5 or $1 \mathrm{~cm}^{3}$ sub-samples were taken at $5-\mathrm{cm}, 10-\mathrm{cm}$ or 20 $\mathrm{cm}$ intervals along the cores.

Mineralogical and chemical analysis The samples were dried in the lab at room temperature, pulverized and subjected to mineralogical and chemical analysis. The identification of minerals was carried out by X-ray diffractometry (Philips model PW 3710, copper anode, adjusted to $45 \mathrm{kV}$ and $40 \mathrm{~mA}$; from 5 to $65^{\circ} 2 \theta$ and steps of $0.02^{\circ}$ ). The XRD-results were compared to ICDD supported by APD software. For mineral identification we also use infrared spectroscopy (Perkin Elmer 1760 X FT-IR; from 4000 to $400 \mathrm{~cm}^{-1}$, measurements at each $\left.4 \mathrm{~cm}^{-1}\right)$ and differential thermal and thermogravimetric analysis (STA 1000/1500 Stanton Redcroft LTD) at the Centro de Geociências/Universidade Federal do Pará. The micromorphology of the minerals and of organic materials was observed under the scanning electron microscope (SEM) and Energy Dispersive System (EDS 500 DP) at Museu Paraense Emílio Goeldi (LEO 1450VP).

Chemical analyses were been carried out at the chemical facilities of Centro de Geociências/Universidade Federal do Pará. Wet chemical analysis and AAS were performed for major elements and some trace elements. $\mathrm{FeO}, \mathrm{S}, \mathrm{Cl}$ and $\mathrm{C}_{\text {org }}$, as well as trace elements, were also analyzed in Lakefield-Geosol, Belo HorizonteMG, Brazil, by AAS, ICP-AES, and X-ray fluorescence. Chlorine was determined by electrode with specific ion and stoichiometric balanced with sodium, as no other sodium mineral was identified than halite. Jarosite is not common. The physical parameters such as $\mathrm{pH}$, Eh, salinity and alkalinity of the sediment were measured in the laboratories of Centro de Geociências and Museu Paraense Emílio Goeldi. Using the whole chemical analysis and stoichiometric calculation we performed the quantification of the minerals.

Pollen analysis Prior to processing, one tablet of exotic Lycopodium spores was added to each sample for calculation of pollen concentration (grains $/ \mathrm{cm}^{3}$ ). All samples were prepared using standard pollen analytical techniques and acetolysis (Faegri \& Iversen 1989). Sample residues were mounted in a glycerine gelatine medium. Pollen morphological descriptions published by Behling (1993), Roubik \& Moreno (1991) carried out the identification of

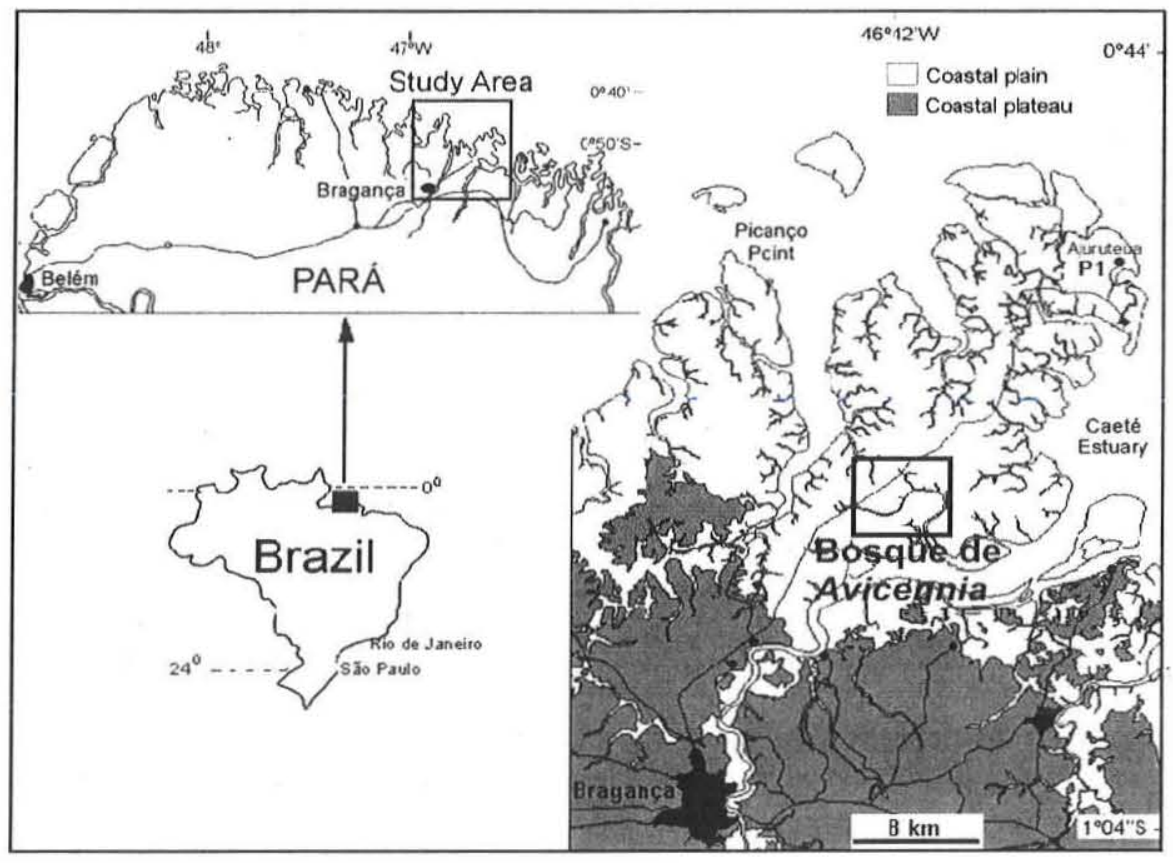

Figure 1 - Location of the study area. 
pollen grains and spores, and the second author of this paper owns a reference collection. In each sample a minimum of 300 pollen grains were counted for the total pollen sum, which excludes fern spores and the micro-foraminifers. Pollen and spore data are presented in pollen diagrams as percentages of the total pollen content. Pollen taxa were grouped into mangrove, other shrubs and trees, palms, herbs, and ferns. The software TILIAGRAPH was used to plot the pollen diagrams. TILIA was used for calculations of pollen taxa (Grimm 1987).

RESULTS AND DISCUSSIONS Geological aspects and stratigraphy of the sediment core The studied area is located in the coastal zone of the northeastern part of Pará State, about $20 \mathrm{~km}$ distant from the city of Bragança. This very flat region developed on typical coastal sediments, including dunes, palaeodunes, beaches and palaeobeaches and mangrove channels. All this materials, which constitute this complex landscape, have developed over lateritic soils derived from sediments of the Barreiras Formation, which is the source area for the coastal sediments.

The sediments of the $640-\mathrm{cm}$ long cores of the Avicennia forest consist mainly of relatively homogenous organic rich mangrove deposits. At the base of the core $(640-620 \mathrm{~cm})$ is found fine, sandy, grey organic matter. The upper core section $(620-0 \mathrm{~cm})$ is compact grey to greenish organic matter. The organic material contains a high content of water, and becomes hard by drying, even at room temperature. As a consequence, white small crystals precipitate mostly halite. Up to $18 \mathrm{wt} \%$ of organic matter was measured in sub-samples at $200-210 \mathrm{~cm}$ core depth. However, the content of organic matter decreases with the depth. Radiocarbon dates show that the studied profile is no older than $2088+/-39{ }^{14} \mathrm{C}$ yr. BP at $540 \mathrm{~cm}$ depth (lower zone), $1830+/-23{ }^{14} \mathrm{C} \mathrm{yr}$. BP at $240 \mathrm{~cm}$ depth (upper zone) and less than $180{ }^{14} \mathrm{C}$ yr. BP for the interval 55 to $0 \mathrm{~cm}$, the top of the upper zone. The sedimentation rate was high in the bottom part of the lower zone, decreased in the last 1800 years and increased again in the upper section (180 yr. BP).

Physicochemical parameters Only the upper samples (AV 0-10 to AV 200-210 cm) show an acid pH (Table 1). From 300 to $610 \mathrm{~cm}$ the $\mathrm{pH}$ ranges from close to neutral to alkaline (6.69 to 7.79). On the other hand the Eh values are highest at the surface $(249 \mathrm{mV})$ and decrease continuously to depth. The most expressive change takes places from 300 to $400 \mathrm{~cm}$ in depth, following the $\mathrm{pH}$. The $\mathrm{pH}$ and Eh parameters led to recognize two important zones along the study core: an acid and oxidized upper zone from surface to less than $300 \mathrm{~cm}$ deep and a slight alkaline and reduced zone from 300 $\mathrm{cm}$ to $610 \mathrm{~cm}$ deep. The salinity measured in the field increases from bottom to top. Halite crystals can be observed in the dried samples, and are very common under SEM-images. The frequent occurrences of halite in the sediments show that the mangrove deposits has been strongly influenced by ocean water incursion. The low $\mathrm{pH}$ values found at the upper part of the core, correspond to the normal $\mathrm{pH}$ values measured in mangrove zone colonized by Avicennia. Their sedimentary characteristics (Rodrigues et al. 2000, Reise \& Schories 2000) promote a rapid leaching and oxidation of the pre-existing sulphides giving origin to jarosite and gypsum. The evaporation processes including evapo-transpiration, bring the water table to the surface making possible the crystallisation of halite.

Mineralogical composition and Organic Matter The minerals that form the muds of Avicennia forest are smectite (probably saponite), kaolinite, quartz, feldspars, pyrite and halite (Table 2). Jarosite and gypsum also occur.

Clay minerals Are the most abundant minerals; alone smectite is dominant ( 35 to $56 \%$ ). This mineral shows low cristallinity at XRD, indicated by its very large and weak peaks. The whole chemical analysis confirms the saponite nature (Table 1). Smectite is not common clay mineral in the studied region, where takes place a very strong tropical weathering with widespread formation of kaolinite instead of smectite. It is concluded that smectite is a newly formed mineral in this mud. On the other hand the kaolinite of this mangrove mud shows a higher degree of cristallinity than smectite, but its peaks are still wide and develop only one reflection

Table I - Chemical composition (Wt.\%), organic carbon (Wt. \%), pH and Eh of mangrove muds of the Bosque de Avicennia drill core, Bragança, Brazil.

\begin{tabular}{|c|c|c|c|c|c|c|c|c|}
\hline & \multicolumn{7}{|c|}{ Samples/Depth $(\mathrm{cm})$} & \multirow[b]{2}{*}{ Mean } \\
\hline & $\begin{array}{l}\text { AV } \\
0.10\end{array}$ & $\begin{array}{c}A V \\
100-110\end{array}$ & $\begin{array}{c}A V \\
200-210\end{array}$ & $\begin{array}{c}\text { AV } \\
300-310\end{array}$ & $\begin{array}{c}\text { AV } \\
400.410\end{array}$ & $\begin{array}{c}A V \\
500-510\end{array}$ & $\begin{array}{c}A V \\
600-610\end{array}$ & \\
\hline $\mathrm{SiO}_{2}$ & 48.28 & 45.81 & 44.05 & 56.29 & 60.97 & 64.72 & 65.99 & 55.16 \\
\hline $\mathrm{Al}_{2} \mathrm{O}_{3}$ & 20.60 & 17.88 & 12.80 & 16.62 & 13.21 & 12.75 & 12.42 & 15.18 \\
\hline $\mathrm{Fe}_{2} \mathrm{O}_{3} \mathrm{t}$ & 6.07 & 6.28 & 4.04 & 5.73 & 5.26 & 4.18 & 4.82 & 5.20 \\
\hline $\mathrm{FeO}$ & 5.46 & 5.65 & 3.64 & 5.16 & 4.74 & 3.76 & 4.33 & 4.68 \\
\hline $\mathrm{TiO}_{2}$ & 0.60 & 0.72 & 0.27 & 0.72 & 0.69 & 0.48 & 0.63 & 0.59 \\
\hline $\mathrm{CaO}$ & 0.15 & 0.24 & 0.37 & 0.17 & 0.35 & 0.95 & 0.42 & 0.39 \\
\hline $\mathrm{MgO}$ & 1.50 & 1.73 & 1.60 & 1.40 & 1.24 & 1.26 & 1.09 & 1.40 \\
\hline $\mathrm{Na}_{2} \mathrm{O}$ & 2.49 & 4.20 & 4.14 & 2.06 & 2.06 & 1.80 & 1.47 & 2.60 \\
\hline $\mathrm{K}_{2} \mathrm{O}$ & 1.48 & 1.54 & 1.29 & 1.49 & 1.34 & 1.28 & 1.24 & 1.38 \\
\hline $\mathrm{Cl}$ & 2.87 & 5.19 & 5.00 & 2.23 & 2.24 & 1.88 & 1.53 & 2.99 \\
\hline $\mathrm{P}_{2} \mathrm{O}_{5}(\mathrm{ppm})$ & 657 & 176 & 262 & 270 & 362 & $<10$ & 32 & $<657$ \\
\hline $\mathrm{LOI}$ & 14.05 & 14.80 & 25.58 & 10.73 & 10.38 & 8.84 & 8.56 & 13.28 \\
\hline S & 4.86 & 5.03 & 3.24 & 4.59 & 4.22 & 3.35 & 3.86 & 4.16 \\
\hline $\mathrm{OC}$ & 5.05 & 5.25 & 7.18 & 5.25 & 4.6 & 3.92 & 3.41 & 4.95 \\
\hline $\mathrm{pH}$ & 5.22 & 5.95 & 5.76 & 6.77 & 7.71 & 7.83 & 7.53 & 6.68 \\
\hline $\mathrm{Eh}(\mathrm{m} \mathrm{V})$ & 245.1 & 227.5 & 207.9 & 212.0 & 184.7 & 177.0 & 176.6 & 204.4 \\
\hline
\end{tabular}


Table 2 - Mineralogical composition (Wt. \%) of the mangrove muds of the Bosque de Avicennia drill core, Bragança, Brazil.

\begin{tabular}{cccccccc}
\hline Samples/Depth(cm) & Kaolinite & Feldspars & Smectite & Quartz & Pyrite & Halite & TOTAL \\
\hline AV-0-10 & 24.0 & 8.7 & 48.0 & 4.4 & 9.1 & 4.7 & 98.9 \\
AV-100-110 & 12.9 & 9.1 & 55.8 & 2.4 & 9.4 & 7.9 & 97.5 \\
AV-200-210 & 2.8 & 7.7 & 51.6 & 8.6 & 6.1 & 7.8 & 84.6 \\
AV-300-310 & 15.2 & 8.7 & 45.2 & 18.1 & 8.6 & 3.9 & 99.7 \\
AV-400-410 & 9.6 & 7.9 & 40.0 & 28.8 & 7.9 & 3.9 & 98.1 \\
AV-500-510 & 8.2 & 7.6 & 40.6 & 33.0 & 6.3 & 3.4 & 99.1 \\
AV-600-610 & 10.3 & 7.3 & 35.2 & 36.6 & 7.2 & 2.8 & 99.4 \\
Mean & 11.8 & 8.1 & 45.2 & 18.8 & 7.8 & 4.9 & \\
\hline
\end{tabular}

Jarosite is present in low quantity but still detected by XRD.

at 4.2-4.5 $\AA$. Kaolinite comprises 3 to 24 wt. $\%$ and probably comes from the nearby landscape formed over tropical weathering products, where kaolinite and quartz are the most common weathering minerals. The partial lack of cristallinity of kaolinite in mud sediments should be an indication of its alteration into smectite inside the muds, when it comes in contact to silica rich microorganisms (diatoms) which are very common in the mud sediments investigated. The role of diatoms to clay formation during the early diagenesis in shelf muds has been described by Michalopoulos \& Aller (2000).

Kaolinite and smectite form a mass of micrometer aggregates of crystals, which imbricate closely (Figs. 2a, b and c). The SEMimages show a clear reaction between kaolinite and diatoms. This reaction probably leads to the formation of smectite, since these microorganisms are made of amorphous silica.

Feldspars Were identified only by $\mathrm{x}$-ray diffraction and could not be observed under optical microscope because their fine grain. They show microcline pattern after the x-ray diffractograms, confirmed by by the relatively high contents of $\mathrm{K}_{2} \mathrm{O}$ (1.2-1.5 wt.\%) (Table 1), which correspond 7 to $9 \mathrm{wt} . \%$ of this mineral. Feldspar crystals could not be clear by observed even by SEM, but SEM/ EDS analyses of the clayey matrix show relative high contents of $\mathrm{K}_{2} \mathrm{O}$, which indicate the intergrowth of feldspars with clay minerals. Again, the presence of diatoms, kaolinite and high content of halite must favor the formation of feldspars too. This is not an expected mineral in such material for this region, for the same reason as smectite, because very strong lateritic weathering takes place in the region since the Early Tertiary. This suggests a new formation of feldspars and smectite in the mangrove muds.

Quartz Is common (2 to 36 wt.\%) (Fig. 2 b) and occurs in the sand to silt fractions. Small part of what we calculated as quartz must be considered to be siliceous organic matter, mainly diatoms (Figs. 2a, b, c, d), as above discussed. Several quartz grains are enveloped by halite (Fig. 2b).

Pyrite Is another frequent mineral found in the mud around 6 to $9 \mathrm{wt} . \%$ and is very closely related to organic matter, by replacing its organic framework. Pyrite is a typical mineral formed inside of the muds and found in several mangrove sediments (Aragon 1997, Oliveira et al. 2002, Roychoudhury et al. 2003). It forms sub micrometer crystal, still difficult to picture by SEM but well crystalline at XRD.

Halite Occurs in all samples, from ca. 3 to 9 wt.\% (Fig. 2). There is halite formed naturally in the sediment pores and also halite formed during the drying of the sample. Halite masses and well- developed cubic crystals (Fig. 2f) fill the pore and enclose quartz grains and clay particles (Fig. 2b).

Jarosite Has been detected from 200 to $610 \mathrm{~cm}$ depth. The presence of jarosite may indicate that a slight oxidation occurred inside of the mud section, from 610 to $200 \mathrm{~cm}$ core depths, promoted by root activity and crab activity. Sub millimeter round aggregates of jarosite(Fig. 2) were formed during the drying of the samples in a room with air-conditioned. MEV/EDS microprobe analyses and images indicate the presence of gypsum (Fig. $2 \mathrm{~g}$ and $2 \mathrm{~h}$ ) as the most frequent sulfate instead of jarosite.

Organic Matter The abundance of pyrite show how important is the contribution of organic matter with high microorganism activity, mainly bacterial. The content of organic matter (vegetal debris) is expressive and reaches $18 \mathrm{wt} . \%$ at 200 to $210 \mathrm{~cm}$ depth. Diatoms occur along the section, as complete organisms or as small fragments (Fig. 2) as part of the clayey matrix, sometimes forming a complex mass and leading to formation of complex clay minerals like smectite when in contact to kaolinite (Fig. 2).

Mineral distribution The near surface sample (AV 0-10 cm) can be distinguished by its relative high content of kaolinite and lower content of smectite, feldspars, pyrite and halite in comparison with the adjacent following, deeper sample (AV $100-110 \mathrm{~cm})$. While the content of kaolinite and pyrite in general decrease with depth, the content of smectite, feldspar and halite decrease continuously (Table 2 and Fig. 3). On the other hand the contents of quartz and diatoms increase very strongly with depth. There is a good correlation between the enrichment of clay minerals and that of pyrite, halite and feldspar and the accumulation of organic matter (vegetal debris). The relative increase of salt from the bottom to the top is outstanding. At 200-210 cm depth (sample AV 200-210) one observes a clear change in the environment indicated by very strong accumulation of organic (vegetal) matter and little contribution of sand-silt and clay mineral (kaolinite mainly). The whole mineralogical behavior indicates that the studied section shows a clear and continuous environmental change, with loss of energy, which is responsible for the decreasing of the sand-silt contribution and for an enrichment of the clay minerals from the bottom to the top. This decreasing of dynamic energy probably was caused by a dense development of the vegetation, fixing the clay fraction and promoting the accumulation of organic material. The elevation of salt content in the upper part, indicated by halite formation and increasing of salinity shows a strong contribution of marine water during the recent times, possibly as water intrusion.

Chemical composition The chemical composition (Table 1, Fig. 

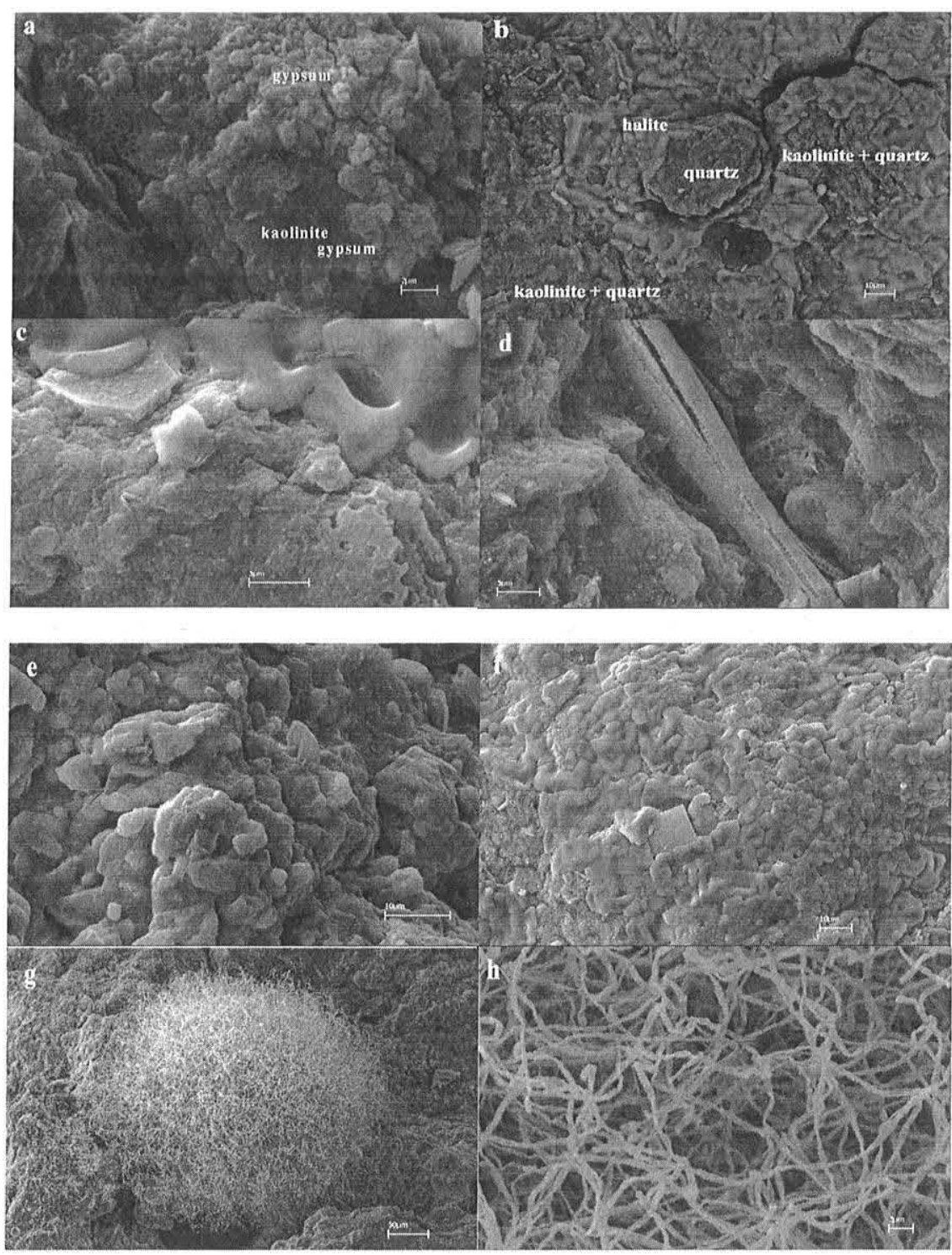

Figure 2 - Images of scanning electron microscopy of mangrove muds and their organic and inorganic components. a) Muds made of clays and diatoms microparticles and neoformation of gypsum. White bar (scale) $=2 \mu \mathrm{m} ; b$ ) Quartz grains with strong invasion of halite. White bar (scale) $=10 \mu \mathrm{m} ; \mathrm{c})$ A masse of clays particles (kaolinite and smectite) showing intergrowth with diatoms. The clay minerals (kaolinite) absorve the diatomes bodies and form possibly smectite. White bar (scale) $=5 \mu \mathrm{m} ; \mathrm{d}$ ) Mud made of aggregates of clays and diatoms. In the center of the image a complete and long body. White bar (scale $)=5 \mu m ; e$ ) halite crystasl invade the mud body. White bar (scale $)=10 \mu \mathrm{m} ; \mathrm{f}$ ) halite crystals invade partly the mud. White bar (scale $)=10 \mu \mathrm{m} ; \mathrm{g})$ Hemi-sphere of room-formed gypsum over mangrove mud. White bar (scale) $=50 \mu \mathrm{m} ; \mathrm{h}$ ) Details of the vermicular materials, which constitute the gypsum hemispheres. White bar $($ scale $)=2 \mu m$.

4) shows that the studied mangrove muds are composed mainly by $\mathrm{SiO}_{2}, \mathrm{Al}_{2} \mathrm{O}_{3}, \mathrm{FeO}$ and $\mathrm{S}$, all above $3 \mathrm{wt} \% ; \mathrm{SiO}_{2}$ and $\mathrm{Al}_{2} \mathrm{O}_{3}$ are the most abundant and comprise together more than 56 wt. $\%$. This constitutes quartz, diatomaceous materials and clay minerals (kaolinite and smectite). $\mathrm{Fe}$ and $\mathrm{S}$ correspond to pyrite. $\mathrm{Na}_{2} \mathrm{O}$ and $\mathrm{Cl}$ show significant values, from 1.5 to $4.2 \mathrm{wt} \%$ and 1.5 to $5.2 \mathrm{wt} \%$ respectively, and constitute basically halite. The values are relatively high for mangrove sediments. $\mathrm{K}_{2} \mathrm{O}$ reaches 1.2 to $1.5 \mathrm{wt} . \%$ and is correlated with microcline; $\mathrm{MgO}$ reaches 1.1 to $1.7 \mathrm{wt} . \%$ and can be related to smectite, probably saponite. Both $\mathrm{K}_{2} \mathrm{O}$ and $\mathrm{MgO}$ contents are also relatively high for mangrove sediments. $\mathrm{CaO}$ shows values are below $0.4 \%$, only one sample displays $0.9 \mathrm{wt} . \%$ as calcite after XRD determinations. The contents of $\mathrm{TiO}_{2}$ are around $0.7 \mathrm{wt} \%$. The content of these elements and the dominance of quartz and kaolinite make possible to interpret the weathered products of Barreiras Formation, formed by sedimentary rocks (siltstones, sandstones and argillites), as a source material, since they constitute the landscape of the studied region. While the concentrations of $\mathrm{SiO}_{2}, \mathrm{Al}_{2} \mathrm{O}_{3}, \mathrm{FeO}$ and $\mathrm{TiO}_{2}$ can be well correlated to the mineral products (laterites and lateritic soils) of the tropical weathering developing in the region, the high content of $\mathrm{K}, \mathrm{Na}, \mathrm{Cl}$, $\mathrm{Mg}$ are not found in these materials. They got into solutions during 


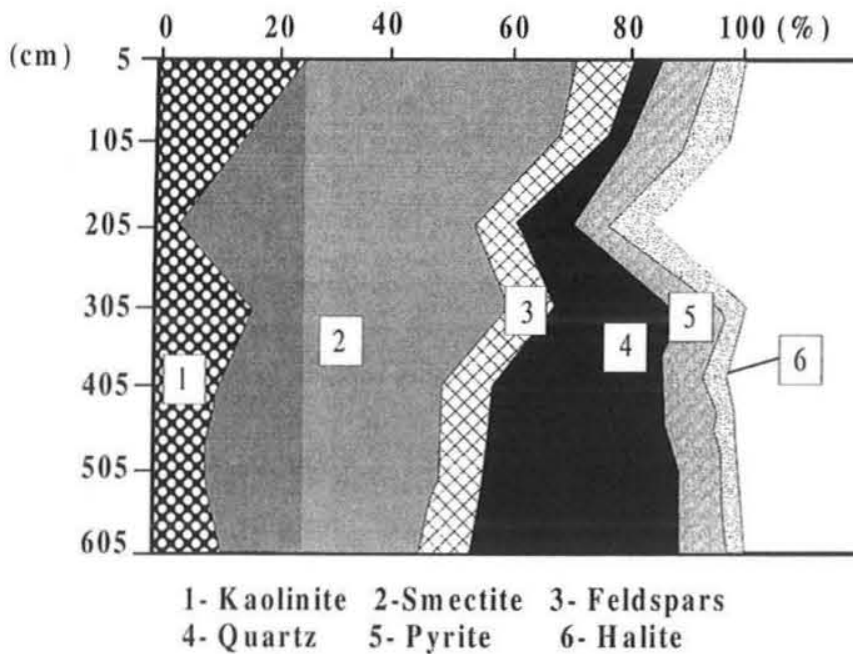

Figure 3 - Mineralogical composition and its distribution along the Bosque de Avicennia drill core, Bragança, Brazil.

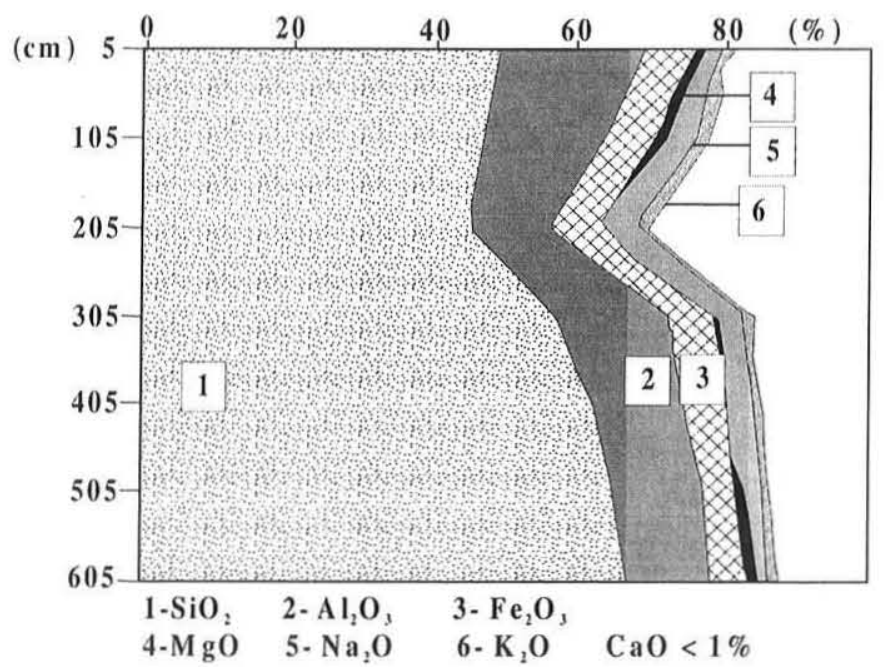

Figure 4 - Distribution of the main chemical elements along the Bosque de Avicennia drill core, Bragança, Brazil.

the tropical weathering and were carried out probably until the ocean coastal plain. No other rocks in the region display these elements in such high contents as the mangrove core studied here. The mud sediments of mangrove may have constituted the barrier for these chemical components coming directly from the continental landscape or from the intrusion of ocean water into the mangrove, as indicated by the strong salinisation and diatoms formation. $\mathrm{Na}$, and $\mathrm{Cl}$ as halite, $\mathrm{K}$ as feldspars and $\mathrm{Mg}$ as complex clay mineral reinforce the establishment of strong marine influence.

The contents of trace-elements (Table 3 ) are low to very low, generally below the Earth Crust average, and their value can be correlated to the sediments, which constitute the Barreiras Formation and the soils derived from it or even from granitic rocks found as small windows in the region. These rocks may have been the source material of great part of the study mangrove muds and are widespread in the region. They are constituted mostly of quartz and kaolinite, and some goethite and hematite. Most of the Fe oxides have been transformed into pyrite in the mangrove sediments as observed by Roychoudhury et al. (2003). The good correlation between $\mathrm{Cr}$ and $\mathrm{V}$ (Fig. 5) reinforces the presence of these minerals. Cluster analyses (Fig. 6) for all investigated chemical elements display the following associations, which can be in an first approximation correlated to most common mineral found in the muds, except kaolinite and quartz, they normally do not carry any significant trace element concentration: $\mathrm{Al}-\mathrm{K}-\mathrm{F}-\mathrm{Mg}$, which are the main chemical components which compose the smectite; $\mathrm{Cu}-\mathrm{Ba}-\mathrm{Y}-\mathrm{Ni}-\mathrm{Na}$ and $\mathrm{Co}-\mathrm{Ti}-\mathrm{Cr}-\mathrm{V}-\mathrm{Ga}-\mathrm{Zn}-\mathrm{Pb}-\mathrm{Fe}$, which are elements normally found associated to smectite and pyrite; and $\mathrm{Si}-\mathrm{Mn}$ possibly related to diatoms. Elements like $\mathrm{Ba}, \mathrm{Sr}, \mathrm{Mg}, \mathrm{Na}, \mathrm{Cl}$ and $\mathrm{F}$ are normally not related to soils and terrigeneous sediments of tropical region as found in studied region made in great part of kaolinite, quartz and hematite/goethite. They are elements that can be found in the marine water and enter the mangrove muds after the intrusion and interaction with ocean water.

Pollen Data The pollen percentage diagram from the $640-\mathrm{cm}$ long core of the Avicennia forest (Fig. 7) shows pollen sums of different groups and the most abundant pollen taxa out of the 80 different types that have been recognized. Based on cluster analysis and marked changes in the pollen assemblages, 3 pollen zones were recognized in the pollen record. Three radiocarbon

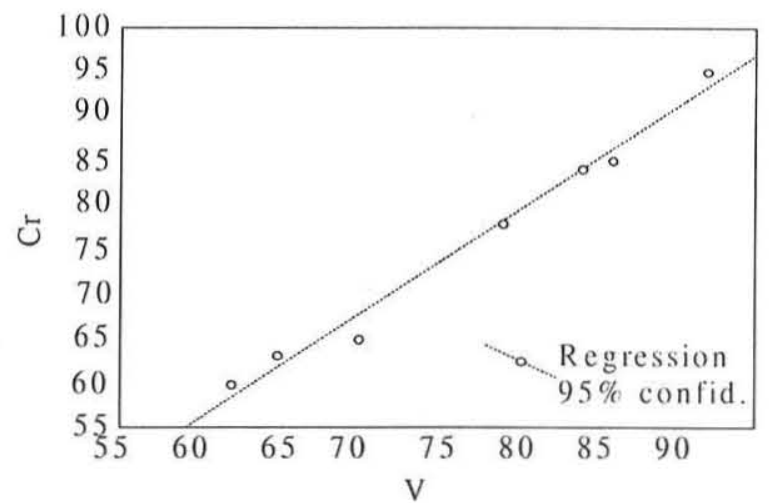

Figure 5 - Bivariate plot of $\mathrm{V} v \mathrm{Cr}$ : $\mathrm{Cr}=13,20+1,1589 * \mathrm{~V}(\mathrm{r}$ $=0.99251)$ in bulk samples of the Bosque de Avicennia drill core, Bragança,Brazil.

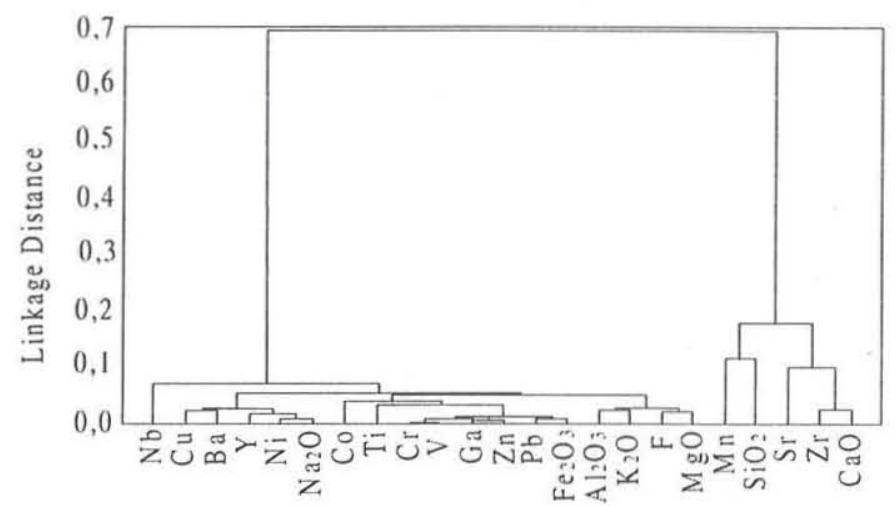

Figure 6-Cluster analyses for chemical elements (Pearson $r$ ) in bulk samples of the Bosque de Avicennia drill core, Bragança,Brazil. 
Table 3 - Trace elements concentration of the mangrove muds of the Bosque de Avicennia drill core, Bragança, Brazil.

\begin{tabular}{|c|c|c|c|c|c|c|c|c|c|}
\hline & \multicolumn{7}{|c|}{ Samples/Depth (cm) } & \multirow[b]{2}{*}{ Mean } \\
\hline & & \multirow{2}{*}{$\begin{array}{c}\text { AV } \\
0-10 \\
60\end{array}$} & \multirow{2}{*}{$\begin{array}{c}\text { AV } \\
100-110 \\
<50\end{array}$} & \multirow{2}{*}{$\begin{array}{c}\text { AV } \\
200-210 \\
300\end{array}$} & \multirow{2}{*}{$\begin{array}{c}\mathrm{AV} \\
300-310 \\
52\end{array}$} & \multirow{2}{*}{$\begin{array}{c}\text { AV } \\
400-410 \\
52\end{array}$} & \multirow{2}{*}{$\begin{array}{c}\text { AV } \\
500-510 \\
71\end{array}$} & \multirow{2}{*}{$\begin{array}{c}\text { AV } \\
600-610 \\
<50\end{array}$} & \\
\hline $\mathrm{ppb}$ & $\mathrm{Hg}$ & & & & & & & & $<300$ \\
\hline \multirow{19}{*}{ ppm } & $\mathrm{F}$ & 600 & 500 & 430 & 640 & 510 & 500 & 420 & 514 \\
\hline & $\mathrm{Se}$ & $<1$ & $<1$ & $<1$ & $<1$ & $<1$ & $<1$ & $<1$ & $<1$ \\
\hline & As & 12 & 24 & 11 & 9 & 12 & 14 & 13 & 13.6 \\
\hline & $\mathrm{Cl}$ & $>5000$ & $>5000$ & $>5000$ & $>5000$ & $>5000$ & $>5000$ & $>5000$ & $>5000$ \\
\hline & Y & 33 & 32 & 31 & 37 & 35 & 33 & 29 & 32.8 \\
\hline & $\mathrm{Zr}$ & 204 & 200 & 376 & 411 & 414 & 487 & 438 & 361 \\
\hline & $\mathrm{Nb}$ & 18 & 12 & 14 & 21 & 25 & 20 & 14 & 17.7 \\
\hline & $\mathrm{Sr}$ & 133 & 149 & 146 & 128 & 139 & 161 & 126 & 140 \\
\hline & $\mathrm{Ba}$ & 260 & 277 & 187 & 292 & 288 & 225 & 206 & 248 \\
\hline & $\mathrm{Ga}$ & 32 & 30 & 28 & 29 & 26 & 21 & 21 & 26.7 \\
\hline & $\mathrm{Pb}$ & 69 & 65 & 47 & 68 & 63 & 54 & 58 & 60.6 \\
\hline & $\mathrm{Cd}$ & $<3.0$ & $<3.0$ & $<3.0$ & $<3.0$ & $<3.0$ & $<3.0$ & $<3.0$ & $<3.0$ \\
\hline & Co & 14 & 14 & 10 & 13 & 12 & 11 & 12 & 12.3 \\
\hline & $\mathrm{Cu}$ & 9,1 & 6,9 & $<3.0$ & 19 & 20 & 16 & 14 & $<20$ \\
\hline & $\mathrm{Cr}$ & 95 & 85 & 65 & 84 & 78 & 60 & 63 & 78 \\
\hline & Mo & $<3.0$ & $<3.0$ & 3 & $<3.0$ & 4,5 & $<3.0$ & $<3.0$ & $<3.0$ \\
\hline & V & 92 & 86 & 70 & 84 & 79 & 62 & 65 & 76.8 \\
\hline & $\mathrm{Ni}$ & $<3.0$ & $<3.0$ & $<3.0$ & 14 & 13 & 8,2 & 3,6 & $<14$ \\
\hline & $\mathrm{Zn}$ & 62 & 60 & 43 & 59 & 53 & 43 & 45 & 52.1 \\
\hline$\%$ & $\mathrm{Mn}$ & 0,02 & 0,02 & 0,02 & 0,02 & 0,02 & 0,03 & 0,03 & 0.02 \\
\hline
\end{tabular}

dates are available for the core depths $540 \mathrm{~cm}: 2088+/-39{ }^{14} \mathrm{C}$ yr. $\mathrm{BP}$ (UtC-8724), $240 \mathrm{~cm}: 1830+/-23{ }^{14} \mathrm{Cyr}$. BP(UtC-8723) and $40 \mathrm{~cm}-15$ $+/-41{ }^{14} \mathrm{C}$ yr. BP(UtC-8722), (Behling et al. 2001). The pollen zones with the calculated age periods are: zone BDA-I (640-175 cm: 2170 $1770{ }^{14} \mathrm{Cyr}$. BP), zone BDA-IIa (175-55 cm: $1770-180{ }^{14} \mathrm{Cyr}$. BP), and zone BDA-IIb (55-0 cm: $180{ }^{14} \mathrm{C}$ yr. BP - modern). Pollen concentration values are low in zone BDA-I (around 15.000 grains/ $\mathrm{cm}^{3}$ ) high in zone BDA-IIa (around 40.000 grains $/ \mathrm{cm}^{3}$ ) and even higher in zone BDA-IIb (around 70.000 grains $/ \mathrm{cm}^{3}$ ). Pollen accumulation rates are higher in zone BDA-I (around 16.000 grains/ $\mathrm{cm}^{2} / \mathrm{yr}$.) than in zone BDA-IIb (around 5.000 grains $/ \mathrm{cm}^{2} / \mathrm{yr}$.) and in zone BDA-IIa (around 7.000 grains $/ \mathrm{cm}^{2} / \mathrm{yr}$.).

The pollen record of Bosque de Avicennia is characterised throughout by the dominance of mangrove pollen, primarily by the high pollen producer Rhizophora (80-90\%). The low pollen producers Avicennia (2-5\%) and Laguncularia (1-2\%) are represented by low values. Minor fluctuations occur between the frequency of Rhizophora and Avicennia pollen during the last $2170{ }^{14} \mathrm{Cyr}$. BP.

There are a high number of different other shrub and tree taxa, such as Anacardium, Moraceae/Urticaceae, Myrtaceae, Virola, Malpighiaceae, Mimosa, Fabaceae, Didymopanax, Symphonia, palms such as Euterpe/Geonoma-type, Orbignya-type, and herb taxa, e.g. Poaceae, Cyperaceae, Amaranthaceae/Chenopodiaceae, Gomphrena/Pfaffia, Alternanthera and Borreria. Only single pollen grains or less than $1 \%$ represents most of these taxa. Some taxa, such as Anacardium, Mimosa, Poaceae, Cyperaceae and Borreria and Alternanthera are somewhat more frequent. The presence of different pollen grains from other shrubs and trees (3$6 \%)$, palms $(0-2 \%)$, herbs $(2-4 \%)$, aquatics $(<1 \%)$ and fern spores $(1-3 \%)$ is relatively stable, but slightly lower in the zone BDA-II. Interesting is the markedly higher occurrence of marine microforaminifers in the sediment deposits of zone BDA-I (3-9\%) than in zone BDA-II (1-2\%).
The formation of the mangroves at the Bosque de Avicennia site $\left(640 \mathrm{~cm}\right.$ lower than today) around $2170{ }^{14} \mathrm{C} \mathrm{yr}$. BP, may indicate that the sea level decreased and allows the development of mangrove vegetation at that site. The very high sedimentation rate in the core Bosque de Avicennia of $465 \mathrm{~cm}$ within 400 years between 2170 and $1770{ }^{14} \mathrm{C} \mathrm{yr}$. BP $\left(=1.16 \mathrm{~cm}^{3} / \mathrm{yr}\right.$, $)$ and the low concentration of pollen grains indicate a rapid deposition. The sea level must have been relatively high. Tidal inundation was frequent and deposited sediments at higher rate during that time. The relatively high occurrence of marine micro-foraminifers and the slightly higher presence of herbs and none forest trees and shrubs, which were probably mostly transported from the inland by rivers, clearly support this interpretation. After $1770{ }^{14} \mathrm{C}$ yr. BP, the sedimentation rate changed $\left(0.1 \mathrm{~cm}^{3} / \mathrm{yr}\right)$ and pollen concentration as well as the presence of micro-foraminifers decreases markedly. The frequency of inundation was now markedly reduced, probably as a consequence of a lower sea level. It should also be considered that the location was at $1770{ }^{14} \mathrm{C}$ yr. BP already $465 \mathrm{~cm}$ higher and the area was filled with mangrove deposits. Highest pollen concentrations during the last $200{ }^{14} \mathrm{C}$ yr. BP, suggest a further reduction of inundation frequency.

The pollen concentration in relatively undisturbed mangrove deposits, such as Bosque de Avicennia, seems to be a good indicator for the frequency of inundation. This correlation has to be improved in future studies. The modern relationship of pollen concentration from the Bosque de Avicennia site (average of 70.000 grains $/ \mathrm{cm}^{3}$ in zone AVI-IIb) and the present-day frequency of inundation ( 74 days/yr.) can be used for the calculation of past inundation frequency. Using this correlation, the average concentration of 40.000 grains $/ \mathrm{cm}^{3}$ in zone AVI-IIa has an inundation frequency of 130 days/yr. and 15.000 grains $/ \mathrm{cm}^{3}$ in zone AVI-I have a value of 345 days/yr.

CONCLUSION The geological data of the studied mud core of 


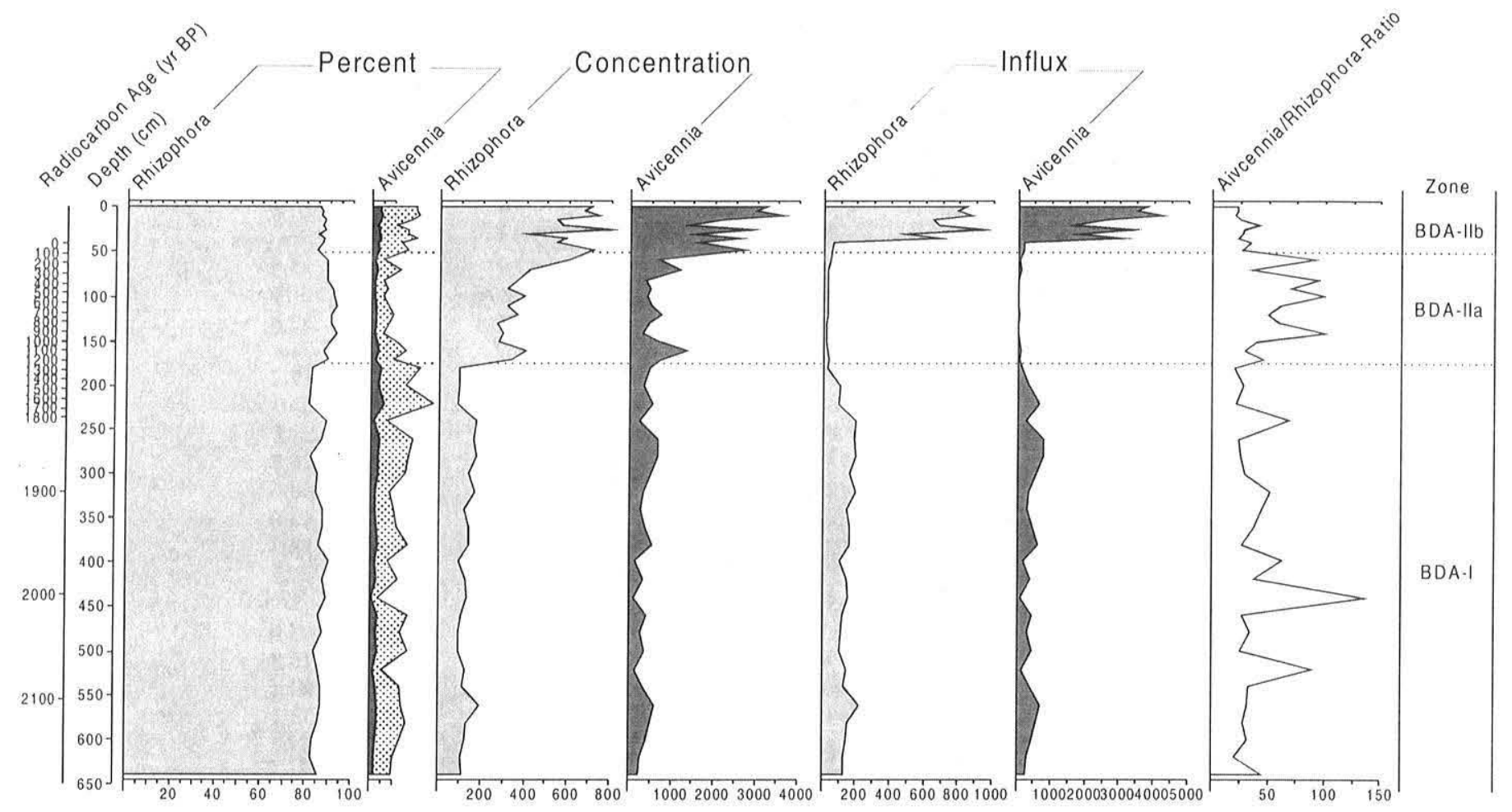

Figure 7 - Pollen diagram showing sums of vegetation groups, percentages of the most frequent pollen taxa, total pollen sum, other taxa, concentration and accumulation rate of pollen and CONISS cluster analysis of the Bosque de Avicennia drill core, Bragança, Brazil. This figure also includes the three radiocarbon dates.

Bosque de Avicennia near Bragança do not show any strong changes in the $640 \mathrm{~cm}$ long profile, except for an enrichment of sand towards the lower level. It looks quite homogeneous and consists basically of compact grey to greenish organic material. The content of organic matter increases from the base to the top. Stronger changes occur above $300 \mathrm{~cm}$ in depth. Interesting is the higher occurrence of marine micro-foraminifers in the interval from 640-175 cm (BDA-I). The studied mud core, deposited in the last $2170 \mathrm{yr}$. BP, initially very fast, then slowly and during the last 180 yr. BP fast again.

On the other hand, the $\mathrm{pH}$ and Eh, as well as the relative salinity led to characterize two important zones in the core: an alkaline, reduced and less salty zone from the base until $300 \mathrm{~m}$ depth, and a slight acid and oxidizing zone with high concentration of halite (high salinity) from $300 \mathrm{~cm}$ to the surface.

The identified minerals species are the same along the profile, and include smectite, kaolinite, quartz, feldspar, halite, pyrite, jarosite and gypsum. There are some changes in their distribution along the sequence. Quartz, indicating a terrigenous phase, dominates in the lower zone, while the clay minerals (smectite and kaolinite), feldspar, pyrite and halite dominate in the upper zone. There are also significant contents of diatoms, which show close intergrowth with the clay minerals as contact reaction. Kaolinite and smectite show low cristallinity, specially the former. Smectite and feldspar are unexpected minerals in the mangrove mud considering the tropical climatic condition of this region.

The chemical composition indicates some changes allowing the recognition of two zones. The most important are $\mathrm{SiO}_{2}$, which increases in the lower zone, while $\mathrm{Al}_{2} \mathrm{O}_{3}, \mathrm{MgO}, \mathrm{Na}_{2} \mathrm{O}$ and $\mathrm{K}_{2} \mathrm{O}$ decrease. $\mathrm{Mn}, \mathrm{Zr}$ and $\mathrm{Nb}$ are more concentrated in the lower zone while the other trace elements display slight increasing in the upper zone, the more organic one. $\mathrm{Zr}$ and $\mathrm{Nb}$ indicate the increase of terrigeneous material in the lower zone. The geochemical associations show a reorganization of the chemical elements into new-formed minerals (mainly pyrite and smectite).

Based on cluster analysis of pollen data and marked changes in the pollen assemblages 3 pollen zones were recognized: zone BDA-I (640-175 cm: 2170-1770 ${ }^{14} \mathrm{C}$ yr. BP); zone BDA-IIa (175-55 cm: $1770-180{ }^{14} \mathrm{C}$ yr. BP); and zone BDA-Ilb $\left(55-0 \mathrm{~cm}: 180{ }^{14} \mathrm{C}\right.$ yr. BP - modern). The pollen record is characterized by the dominance of Rhizophora (80-90\%). This corresponds partly to the lower zone identified by geology, mineralogy and chemistry, which has been deposited very fast (in $400 \mathrm{yr}$.) under relative high sea level conditions, reinforced by high occurrence of marine microforaminifers. The upper zone, acid and oxidizing can be related to BDA-II, with low deposition rate according to pollen concentration rates and the radiocarbon dates. This explains why the zone is acid and oxidizing. During the last 200 years, $55 \mathrm{~cm}$ of mangrove mud were deposited with a high pollen concentration, which suggests a further reduction in the inundation frequency.

The geochemical and mineralogical evolution of mangrove sediments results of the interaction of biotic and abiotic parameters, whose balance is conditioned by the climate that governs the hydrologic regime, the sedimentation dynamics and of the organic matter. Under tropical climate, the strong chemical weathering of the source area supplies quartz, clay minerals (mainly kaolinite), oxidized particulates (iron oxides), besides in water dissolved chemical components (silica, aluminum complexes and ions and 
complexes of heavy metals), that are transported and deposited partly as the mangrove muddy sediments and/or still transported forward in to the ocean. The diatoms and other plantonic materials are also transported and they participate actively of the physical, chemical and biological processes in these sediments.

In general the current chemical composition of mangrove sediments corresponds to the contribution of the source area (mostly made of $\mathrm{SiO}_{2}, \mathrm{Al}_{2} \mathrm{O}_{3}$ and $\mathrm{Fe}_{2} \mathrm{O}_{3}$ and poor in alkali-elements), together with the elevated contents of $\mathrm{K}, \mathrm{Ca}$ and $\mathrm{Mg}$, of marine provenience. The appearance of new mineral phases results, essentially, of the physical and chemical degradation of the organic matter (vegetal and animal) and former mineral phases, now adapted to the new geochemical conditions. In these sediments, which are highly organic and not very permeable, the formation of minerals certainly is favored by the slow and ion enriched flows (interstitial water), as ascribed by Michalopoulos \& Aller (2000).

The presence of expressive amounts of K-feldspar and smectite in the sediments, and their absence in the source material, are strong evidence of the neoformation of these minerals. The neoformation of $\mathrm{K}$-feldspar and smectite is probably due to contribution of $\mathrm{K}^{+}$and $\mathrm{Mg}^{2+}$ from marine water and their concentration by evaporation or ionic diffusion in the surface of the sediments, and $\mathrm{SiO}_{2}$ from diatoms, explaining the largest concentration of these minerals in this area.

The formation of the smectite is evidenced by the degradation of the kaolinite, with the loss of the cristallinity of this mineral. Both possess intrinsic morphologic relationships, clearly observed through the scanning electron microscopy. Yet the formation of the smectite can be considered to start from the contribution of
$\mathrm{Mg}^{2+}$ of marine source, with the high concentrations of silica brought waterway and, with the coming silica from the chemical decomposition of the diatoms silica-rich shells. The richness in silica diatoms favors the rapid transformation of kaolinite into smectite, as observed by Michalopoulos \& Aller (2000).

The formation of the pyrite is related to the availability of iron, found firstly as iron oxides, and to high activity of organic matter, mainly bacteria, which favor the reduction of sulphates come from marine water that enter the mangrove mud sediments (Roychoudhury et al.2003) and iron oxides coming from the neighboring terrestrial sediments and soils. This process explains the largest concentrations of this mineral in the upper part of the sediments. The formation of halite and gypsum also indicate that the near surface material was subjected to strong evaporation after receiving ocean water. At the same time this material was oxidized by root activity and water circulation. The results show that the mangrove section studied here, although no more than 2170 years old, is a very complex system, that display a continuously mineralogical and chemical transformation in order to establish much more an intermediate equilibrium between marine influence and continental contribution, as part of the estuarine environment, than to the tropical climate conditions.

Acknowledgements Financial support was given by $\mathrm{CNPq}$, and laboratory contribution from the Center for Tropical Marine Ecology, Bremen (Germany), Universidade Federal do Pará and Museu Paraense Emílio Goeldi in Belém (Brazil), to which the authors acknowledge. To the RBG reviewers for suggestions to the manuscript.

\section{References}

Aragon G.T. 1997. Biogeoquímica sedimentar do enxofre e do ferro em um manguezal da baía de Sepetiba, RJ: neoformação de sulfetos ferrosos. Tese de Doutoramento, Universidade Federal Fluminense, $119 \mathrm{p}$.

Behling H., Cohen M.C.L., Lara R.J. 2001. Studies on Holocen mangrove ecosystem dynamics of the Bragança Peninsula in northeastern Pará, Brazil. Palaeogeography, Palaeoclimatology, Palaeoecology, 167:22-242.

Behling H. \& Costa M.L. 1997. Studies on Holocene tropical vegetation, mangrove and coast environments in the state of Maranhão, NE Brazil. Quaternary of South America and Antarctic Peninsula, 10 (7):93-118.

Behling H. 1993.Untersuchungen zur Spaetpleistozaenen und Holozaenen Vegetation- unsd Klimageschichte der Trpischen Kuestenwaelder und der Araukarienwaelder in Santa Catarina (Suedbrasilien). Dissertationes Botonicae 206, Cramer. Berlin, 149p.

Behling H., Cohen M.C.L., Lara R.J. 2001. Studies on Holocene mangrove ecosystem dynamics of the Bragança Peninsula in northeastern Pará, Brazil. Palaeogeography, Palaeoclimatology, Palaeoecology, 167:225-242.

Costa Neto S.V., Bastos M.N.C., Lobato L.C.B. 1996. Composição florística e fitofisionomia da restinga do Crispim, Município de Marapanim, Pará. Boletim do Museu Paraense Emílio Goeldi (Sér. Bot.), 12(2):237-249 .

Faegri K. \& Iversen J. 1989. Textbook of pollen analysis. 4 ed. Wiley, Chichester, 328 p.
Grimm, E.C.1987. CONISS: A Fortran 77 program for stratigraphically constrained cluster analysis by the method of the incremental sum of squares. Computer and Geosciences, 13: 13-35.

Harbinson P. 1984. Regional variation in the distribution of trace metals in modern intertidal mangrove sediments of Northern Spencer Gulf, South Australia. Mar: Geol., 61:221-247.

Harbinson P. 1986. Mangrove muds - A sink and source for trace metals. Marine Pollution Bulletin, 17:273-276.

Michalopoulos P. \& Aller R. C. 2000. Conversion of diatoms to clays during early diagenesis in tropical, continental shelf muds. Geology, 28(12):1095-1098.

Oliveira O.M.C., Queiroz A.F.S., Argolo J.L., Roeser H.M.P., Rocha S.R.S. 2002. Estudo mineralógico do sedimento de manguezal da baía de Camamu-BA. Rev. Escola de Minas, 55(2):147-151.

Reise A. \& Schories D. 2000. Forest structure and litter production in fringe mangroves of North Brazil Mangrove. In: Mangrove 2000: Sustentabilidade de Estuários e Manguezais: Desafios e Perspectivas, Recife, Federal Rural University of Pernambuco, 8p, CD-ROM.

Rodrigues K.B., Rocha A., Schories D., Ramos J. 2000. Topografia das áreas degradadas de manguezal de Bragança, Pará, Brasil. In: Mangrove 2000: Sustentabilidade de Estuários e Manguezais: Desafios e Perspectivas, Recife, Federal Rural University of Pernambuco, 8p, CD-ROM.

Roubik D.W. \& Moreno J.E. 1991. Pollen and Spores of Barro Colorado 
Island. St. Louis: Missouri Botanical Garden, Vol. 36.

Roychoudhury A.N., Kostka J.E., Cappellen P. Van. 2003. Pyritization: a palaeoenvironmental and redox proxy reevalutated Estuarine Coastal and Shelf Science, 56:1-11.

Souza Filho P.W.M. 1995. A planície costeira bragantina (NE do Pará): Influência das variações do nível do mar na morfoestratigrafia costeira durante o Holoceno. Dissertação de Mestrado, Centro de Geociências, Universidade Federal do Pará, 123 p.

Souza Filho P.W.M. \& El-Robrini M. 1996. Morfologia, processos de sedimentação e litofácies dos ambientes morfo-sedimentares da planície costeira bragantina, nordeste do Pará, Brasil. Geonomos, $4(2): 1-16$.

Tanizaki-Fonseca K. 1994. Biogeoquímica de metais pesados na rizosfera de plantas de um manguezal da Baía de Sepetiba-RJ. Dissertação de Mestrado, Universidade Federal Fluminense, 68 p.

\section{Manuscrito A-1408}

Recebido em 06 de fevereiro de 2003

Revisão dos autores em 25 de maio de 2004 Revisão aceita em 15 de junho de 2004 